\title{
Premarital Genetic Diagnosis Revealed Co-heredity Nature of Beta Globin Gene 25-26 del AA and 3'UTR+101 G-C Variants in Two Beta Thalassemia Heterozygotes
}

\author{
Iki Heterozigot Beta Talasemi Taşıyıcısında Evlilik Öncesi Genetik Tanı ile Beta Globin Geni 25- \\ 26 del AA ve 3'UTR + 101GC Varyant Kalıtımının Gösterilmesi
}

\author{
Kanay Yararbaş ${ }^{1}$, Yasemin Ardıçoğlu², Nejat Akar ${ }^{3}$ \\ ${ }^{1}$ Düzen Laboratories Group, Ankara, Turkey \\ 2TOBB-ETU Hospital, Clinic of Biochemistry and Clinical Biochemistry, Ankara, Turkey \\ ${ }^{3}$ TOBB-ETU Hospital, Clinic of Pediatrics, Ankara, Turkey
}

To the Editor,

Over 2000 gene variants were reported in the beta globin gene, including hemoglobin variants. These variants are important from clinical and genetic counseling points of view [1,2]. Recently a genetically related Turkish couple was referred to our department for genetic counseling for beta thalassemia carrier status. During premarital screening they were both diagnosed as beta thalassemia carriers by high pressure liquid chromatography analysis and whole blood count (Table 1). Genomic DNAs of both patients were extracted using the QIAamp DNA Blood Midi Kit (OIAGEN, Germany). The $H B B$ gene was amplified using the following polymerase chain reaction (PCR) primers: forward (5'GCCAAGGACAGGTACGGCTG3'), reverse (5'CCCTCCTATGACATGAACTAACCAT3') and forward (5'CAATGTATCATGCCTCTTGCACC $\left.3^{\prime}\right)$ reverse (5'GAGTCAAGgCTGAGGATGCGGA3'). Purifications were done using the ExoSAP purification program (Affymetrix Inc., USA). The BigDye Sequencing PCR technique was used for the analysis (Applied Biosystems, USA). Samples were analyzed with the SeqScape v2.5 analysis program. Common alpha globin gene deletions were analyzed according to the previously reported technique $[3,4]$.
Two different gene alterations were found in the beta globin gene of both partners (Table 1). One of them was a deletion at 25-26AA (rs35497102) (Figure 1). The other gene alteration was a single nucleotide polymorphism at 3'UTR+101 G-C +233 relative to the termination codon (rs12788013) (Figure 2). Neither of the individuals carried the common alpha thalassemia deletions.

Beta globin gene 3'UTR+101 G-C alteration is a single nucleotide polymorphism that was not previously classified and reported as a pathogenic variant $[1,2]$. It seems that carrying $3^{\prime} U T R+101$ $\mathrm{G}-\mathrm{C}$ does not cause any additional clinical features in 25-26 del AA carriers. In this situation there is certainly more than one possibility to be mentioned in genetic counseling. 3'UTR+101 $\mathrm{G}-\mathrm{C}$ being a single nucleotide variant resulting in a decreased expression of the gene causing the beta thalassemia major clinical picture is the most likely one. This is more evident when combined with a disease causing mutation, as previously reported by us and others $[3,4,5,6,7]$. However, from our family's data, this is not valid, because they are beta thalassemia carriers. The main problem in this case is that an expression study was not performed for these individuals.

\begin{tabular}{|c|c|c|c|c|c|c|c|c|c|}
\hline & $\mathrm{Hb}$ & RBC & MCV & $\mathrm{MCH}$ & МСНC & RDW & $\mathrm{HbA2}$ & $\mathrm{HbF}$ & $H B B$ gene variant \\
\hline Male & 10.7 & 5.78 & 55.5 & 18.5 & 33.3 & 18.5 & 4.8 & 1.4 & $\begin{array}{l}\text { Variant 1: } \\
\text { c.25_26AA (rs35497102) } \\
\text { Variant 2: } \\
\text { 3'UTR+101 G-C +233 relative to } \\
\text { termination codon (rs12788013) }\end{array}$ \\
\hline
\end{tabular}




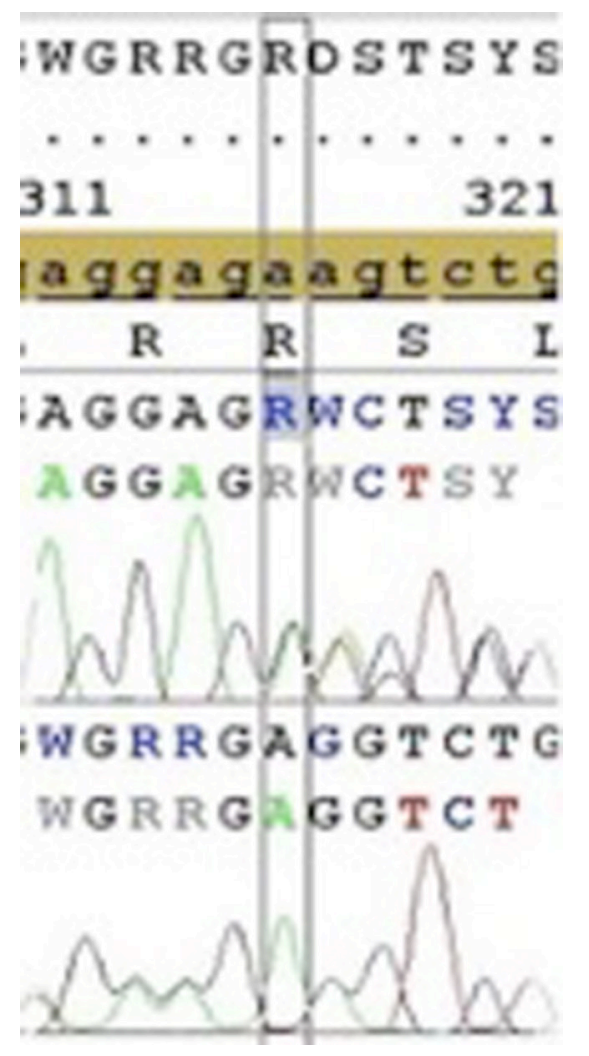

Figure 1. Sequencing data of the deletion at 25-26 AA (rs35497102).

One of the possibilities for the inheritance pattern in this situation is that these two gene variants will be inherited in the "cis" position. In this case, from the genetic point of view, "in cis" is the only acceptable solution for the fetus, which will be similar to the parents. However, if it does not come in the "cis" position, there will be a possibility that the fetus may inherit 3'UTR+101 G-C in the homozygous state (from both parents). Unfortunately, not many publications have discussed similar conditions. For prenatal screening of the fetus, only the del 2526 AA /3'UTR+101 G-C heterozygote state should be accepted as normal.

This case report highlights the need for investigating partnered beta thalassemia carriers by complete sequencing analysis of the beta globin gene if only one pathogenic mutation is detected by first-tier methods for the possibility of providing appropriate genetic counseling for couples at risk during prenatal genetic diagnosis.

Keywords: Thalassemia, Variant, Genetic counseling, Prenatal diagnosis, Beta globin gene, Turkish

Anahtar Sözcükler: Talasemi, Varyant, Genetik danışmanlık, Prenatal tanı, Beta globin geni, Türk

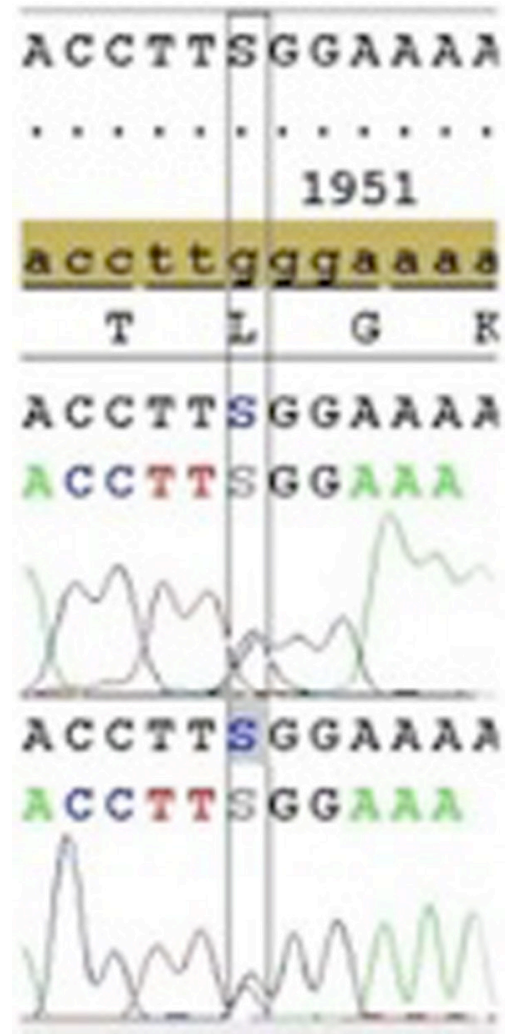

Figure 2. Single nucleotide polymorphism at 3' UTR +101 G-C (+233 relative to termination codon).

Conflict of Interest: The authors of this paper have no conflicts of interest, including specific financial interests, relationships, and/or affiliations relevant to the subject matter or materials included.

\section{References}

1. HbVar: A Database of Human Hemoglobin Variants and Thalassemias. Available online at http://globin.bx.psu.edu/hbvar/menu.html.

2. Human Gene Mutation Database (HGMD) Professional Version 2016.1. Available online at https://portal.biobase-international.com/hgmd/pro/ gene.php?gene=HBB.

3. Oron-Karni V, Filon D, Oppenheim A, Rund D. Rapid detection of the common Mediterranean alpha-globin deletions/rearrangements using PCR. Am J Hematol 1998;58:306-310.

4. Tan AS, Quah TC, Low PS, Chong SS. A rapid and reliable 7-deletion multiplex polymerase chain reaction assay for alpha-thalassemia. Blood 2001;98:250-251.

5. Başak AN, Ozer A, Kirdar B, Akar N. A novel 13 Bp deletion in the $3^{\prime}$ UTR of the beta-globin gene causes beta-thalassemia in a Turkish patient. Hemoglobin 1993;17:551-555.

6. Vinciguerra $M$, Passarello $C$, Leto $F$, Cassarà $F$, Cannata $M$, Maggio $A$, Giambona A. Identification of three new nucleotide substitutions in the $\beta$-globin gene: laboratoristic approach and impact on genetic counseling for beta-thalassemia. Eur J Haematol 2014;92:444-449.

7. Bilgen $T$, Clark OA, Ozturk Z, Akif Yesilipek M, Keser I. Two novel mutations in the $3^{\prime}$ untranslated region of the beta-globin gene that are associated with the mild phenotype of beta thalassemia. Int J Lab Hematol 2013;35:26-30. 